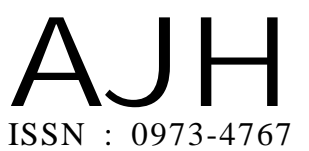

Article history :

Received : 27.10.2019

Accepted : 28.11.2019
RESEARCH NOTE

THEASIAN JOURNALOF HORTICULTURE

Volume 14 | Issue 2 | December, 2019 | 27-29

Visit us -www.researchjournal.co.in
Members of the Research Forum

Associated Authors:

${ }^{1}$ Department of Vegetable Science, University College of Agriculture Guru Kashi University, Talwandi Sabo,

Bathinda (Punjab) India

Author for correspondence :

Navdeep Singh

Department of Vegetable Science,

University College of Agriculture,

Guru Kashi University, Talwandi Sabo,

Bathinda (Punjab) India

Email : navdeep.brar50@gmail.com

\section{Effect of nitrogen and phosphorus on seed yield of coriander (Coriandrum sativum L.)}

\author{
Navdeep Singh and Harpal Singh ${ }^{1}$
}

ABSTRACT : A field experiment was conducted during Rabi season of 2017-2018 to study the effect of nitrogen and phosphorus on seed yield of coriander (Coriandrum sativum L.). The experiment comprising of 16 treatment combinations with four levels of nitrogen viz., 0, 20, 40 and $60 \mathrm{~kg} \mathrm{~N} \mathrm{ha}^{-1}$ and four levels of phosphorus viz., 0, 20, 40 and $60 \mathrm{~kg} \mathrm{P}_{2} \mathrm{O}_{5}$ ha $^{-1}$ was laid out in RBD design with three replications. The experiment results revealed that the combination of 60 $\mathrm{kg} \mathrm{N} \mathrm{ha}^{-1} ; 20 \mathrm{~kg} \mathrm{P}_{2} \mathrm{O}_{5} /$ ha promoted yield attributes viz., number of umbels per plant (14.27), the combination of $60 \mathrm{~kg} \mathrm{~N} \mathrm{ha}^{-1} ; 60 \mathrm{~kg} \mathrm{P}_{2} \mathrm{O}_{5} /$ ha promoted number of seeds per umbellate (5.96), the combination of $60 \mathrm{~kg} \mathrm{~N} \mathrm{ha}^{-1} ; 40 \mathrm{~kg} \mathrm{P}_{2} \mathrm{O}_{5} /$ ha promoted seed weight per plant (4.82 g), the

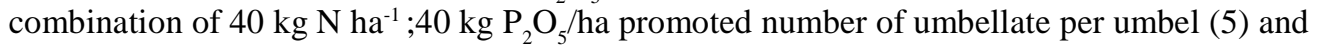
ultimately higher seed yield $\left(1469 \mathrm{~kg} \mathrm{ha}^{-1}\right)$ was given by combination of $60 \mathrm{~kg} \mathrm{~N} \mathrm{ha}^{-1} ; 40 \mathrm{~kg} \mathrm{P}_{2} \mathrm{O}_{5} /$ ha.

KEY WORDS : Coriander, Nitrogen, Phosphorus

HOW TO CITE THIS ARTICLE : Singh, Navdeep and Singh, Harpal (2019). Effect of nitrogen and phosphorus on seed yield of coriander (Coriandrum sativum L.). Asian J. Hort., 14(2) : 27-29, DOI : 10.15740/HAS/TAJH/14.2/27-29. Copyright@2019 : Hind Agri -Horticultural Society 